\title{
Characteristic of Small Scale Food Industry Cluster in West Sumatera
}

\author{
Gunarif Taib $^{\#}$, Santosa ${ }^{\#}$, Masrul Djalal ${ }^{\#}$, Helmi ${ }^{*}$ \\ ${ }^{\text {\# }}$ Faculty of Agricultural Technology, Andalas University, Padang, Indonesia \\ E-mail: gunariftaib@yahoo.com \\ * Faculty of Agriculture, Andalas University, Padang, Indonesia
}

\begin{abstract}
Clusters of small-scale food industries have different characteristics with industrial cluster in general. These characteristics need to know to develop a plan for cluster development. This study was conducted to determine characteristics clusters of small-scale food industry, especially in West Sumatra. For the analysis of the components of industrial and technological components that affect the development of small-scale food industry cluster in West Sumatra. All variables influence the level of industrial components and technology components were analysed using the program "Statistical Product and Service Solutions (SPSS)". The survey results revealed that the industrial component is influenced by the core industry (level of difficulty in capital gain and raw materials), the buyer (customer satisfaction), related industry (quality and continuity of supply of packaging) and institutional support (coaching on marketing and capitalization as well as guidance on the production of sanitary and food safety). Component technology is influenced by organoware (production management and marketing management) and human ware (innovation and trust among the members).
\end{abstract}

Keywords - characteristics; industrial components; component technology; industrial clusters; small scale

\section{INTRODUCTION}

Small and medium scale industries in Indonesia has a strategic function in economic development. When Indonesia's economic crisis, small industries to survive in order to prevent decreasing of the national economy. Small scale industry can create jobs in large numbers. Through the development of appropriate policies and targeted then this sector a major mainstay in the real sector in Indonesia [14]. In West Sumatra, small-scale enterprises dominate the development of the industry. In 2010 small scale industries in number, 93.4 percent and 6.6 percent large-scale medium [7].

Development of small-scale food industry aimed at the following: (a) the food industry clusters integrated with production centers of raw materials and other support facilities, (b) industrial partnerships with large-scale industry, (c) the establishment of regulations on large-scale food industry (d) increasing the competitiveness of high. As a reference in the development of industrial clusters, the government has set a Road Map for the development of the industry [12]. In accordance with existing guidelines, the Government of West Sumatra province to form a group that is incorporated in the "Service Unit and Development of Agricultural Products Processing". This business group is the embryo of a cluster of small-scale food industries in
West Sumatra. Until the year 2013, has formed 126 groups of small-scale food businesses scattered throughout the County / City in West Sumatra [8].

Industrial cluster in Indonesia are generally formed due to the availability of raw materials and labor. Usually the industrial cluster to cluster in certain areas, and has linkages with other industries. Linkages to other industries usually a cooperative relationship [11]. Inter-industry linkages is done at all stages of production, from the provision of raw materials / raw materials, processing, to marketing. The series of events is a synergy in industrial clusters.

\section{MATERIALS AND METHODS}

This study uses observational case study research design. By observation in the case study can be obtained information or information accurate and detailed empirical research analysis unit [2].

Analysis was performed on the following organizations: (a) Service Unit and Development of Agricultural Products Processing considered to represent a collection of smallscale food industry as a core industry; (b) Farmers Group, representing suppliers of raw materials for the food industry; (c) Broker Dealer/Store as a marketing link; (d) Agricultural Department/Department of Industry and Trade/cooperatives/ banking as supporting institutions. 
Research using primary data obtained from all components of the industry. The influence of all parameters on the sustainability of the cluster is determined by regression analysis. All variables influence the level of industrial components and technology components were analyzed using the program "Statistical Product and Service Solutions (SPSS)". Analysis was performed on industrial components as follows: core industry, related industries, buyers, suppliers, and supporting institutions

\section{RESULT AND DISCUSSION}

\section{A. Function of Core Industries}

From the results of regression analysis using known that the level of difficulty to capital gain and raw materials greatly affect the function of the core industries. The influence of these variables can be seen from the following regression equation:

$$
\begin{aligned}
\mathrm{Y}= & -3.162+4.157 \mathrm{X} 1+\mathrm{X} 21.122-0.425+0.355 \mathrm{X} 3 \mathrm{X} 4 \\
& -1.877 \mathrm{X} 5
\end{aligned}
$$

$\left(R^{2}=0.879\right)$

\section{$\mathrm{Y}=$ Function of Core Industries}

Variable X1 (degree of difficulty capital gain) and X2 (the level of difficulty in obtaining raw materials) have a significant influence on the function of core industries. Variable X3 (degree of difficulty increases process technology), X4 (level of difficulty of improving the quality) and X5 (degree of difficulty increases marketing) has no effect on the level of $\alpha=0.05$.

In production, the main raw materials on a small scale food industries in West Sumatra supplied by local farmers. Habits of farmers in planting still influenced by social conditions so that production can not be predicted. under certain conditions of social conditions will affect the business [3].

The selling price of commodities produced is one of the considerations for farmers in determining the commodities to be planted. Commodities are processed into refined product usually will increase the selling price due to the process of adding value to the commodity. Farmers should be able to get the result of value added in manufacturing [18]. Thus, the supply of raw materials to the processing industry to be smooth. The supply of raw materials is greatly influenced the development of industrial clusters. This study also proves that the viability of small industries is strongly influenced by the capitalization issue. One of the main problems in the development of industrial clusters in Indonesia is capital [9]. It is necessary for microfinance institutions, facilitated by the government. It is necessary to overcome the problem of capitalization of business, especially small-scale enterprises.

\section{B. Buyers}

In this study analyzed the components of the buyer is consumer satisfaction, consumer demand, the level of difficulty dealing with the seller / store. The regression equation is the following:
$\mathrm{Y}=2.492+10.025+0.664 \mathrm{X} 1 \mathrm{X} 2-\mathrm{X} 3.892$

$\mathrm{R}^{2}=0.699$

$\mathrm{Y}=$ Buyers

Variable X1 (customer satisfaction) have a significant influence on the role of the buyer. Variable X2 (consumer demand), and X3 (degree of difficulty dealing with the seller /store) had no effect on the level of $\alpha=0.05$.

This study proves that an influential component based on the results of the analysis using the SPSS is "customer satisfaction". The most appropriate way to attract buyers is to consider the needs and desires [15]. In this case the purchaser or consumer satisfaction must be considered by the manufacturer. Further described that there are two main things related to consumer conditions, namely:

1) Identification of the consumer. In this case the consumer could be the use of direct (user), traders diluent, and institutions. For small-scale food industry manufacturers of consumer identity that they face are the direct users (user). For that we need an understanding of consumer tastes, especially with regard to the nature of the product organoleptic (taste, aroma and physical appearance).

2) Demographic factors. In this case to consider the level of income and population. The level of income will affect consumer tastes. It required foresight manufacturers in product quality by adjusting the level of income or purchasing power of consumers.

\section{Function of Institutional Support}

From the analysis it can be seen coaching related to sanitation production and food security is crucial role of supporting institutions. The influence of these variables can be seen from the following regression equation:

$\mathrm{Y}=0.508-0,076 \mathrm{X} 1-1,815 \mathrm{X} 2+8,405 \mathrm{X} 3$

$\left(\mathrm{R}^{2}=0.894\right)$

$\mathrm{Y}=$ The Function of Institutional Support

Variable X2 (guidance on marketing and capitalization) and X3 (guidance on sanitation and food safety) have a significant influence on the role of supporting institutions. Variable X1 (development of raw materials and processing), no effect on the level of $\alpha=0.05$.

Guidance to small businesses related to the production of sanitation and food safety has not been properly enforced. food consumed there are not safe for health [4]. This is because the food safety factor has not been implemented properly. Because it needed guidance regarding sanitary production and food security in developing small-scale food industries. Product specifications and selection of appropriate technology is indispensable for the development of enterprises [6]. In addition, external factors such as supporting agencies related to agro-processing industries will also affect the business [10].

Strong clusters with suppliers of materials and are capable of supporting institutions can improve the productivity of the company. The synergy between the companies will improve the condition of the cluster and the business environment. 
Thus the cluster development with regard to the success of companies and communities that exist in these clusters [15].

\section{Related Industries}

In this study, a component of the related industries analyzed are the quality and continuity of supply of packaging, and transportation. The regression equation is the following:

$\mathrm{Y}=0.203+0.18 \mathrm{X} 1-0,040 \mathrm{X} 2$

$\left(R^{2}=0.710\right)$

$\mathrm{Y}=$ Function of Related Industries

Variable X1 (quality and continuity of supply packaging) have a significant influence on related industries. Variable $\mathrm{X} 2$ (smooth transportation), has no effect on the level of $\alpha=$ 0.05 .

Components that influence the results of the analysis using SPSS quality and continuity of supply of packaging. Continuity necessary for the smooth production of packaging supplies, because in addition to affect the sustainability of production, consumers are also very concerned about the quality of packaging. Product packaging design is very important because it can increase buyer interest at 51.5 percent [16]. This number can be increased by up to 55 percent when linked to the price of the product. Packaging design is influenced by the development of consumer tastes. Lifestyle changes and differences in values that some segments of society also affect the interests of buyers and interest in packaging design. Consumers generally prefer the attractive packaging design, easy to carry and easy to open [13].

\section{E. Organoware}

In this study organoware components analyzed are production management, marketing management, environment management. The influence of these variables can be seen from the following regression equation:

$Y=-0.694+3.361 X 1+0.953 X 2+0.102 X 3$

$\left(R^{2}=0.628\right)$

$\mathrm{Y}=$ Function of organoware component in the core industry

Variable X1 (production management) and X2 (marketing management) have a significant influence on organoware. Variable X3 (environmental management), no effect on the level of $\alpha=0.05$.

Components that influence the results of the analysis using the SPSS is "marketing management" and production management ". Internal environment and external environment as well as the general environment can influence the management strategy in an industry [15]. Technology as one of the components of the general environment will provide great opportunities to improve results thus affecting the progress of the company. Marketing management is responsible for inventory changes in the marketing environment.

Traditional marketing strategies are still trying to convince consumers that they need a product that is produced [1]. In the development of marketing strategy should be changed. Manufacturers have to design marketing in accordance with the needs of consumers. Growth of marketing consists of three types of intensive growth, integrative growth and diversification. In the intensive growth of producers seek opportunities in scale operations that still rely on existing market segments. Integrative growth integrate production activities with market developments. At this stage of diversified manufacturer has been able to enter the market wider than the existing network.

\section{F. Humanware}

In this study analyzed humanware component is innovation, motivation, trust fellow members, knowledge manager, manager skills. The influence of these variables can be seen from the following regression equation:

$$
\begin{aligned}
\mathrm{Y}= & 3.792+15.687+0.072 \mathrm{X} 1 \mathrm{X} 2-\mathrm{X} 32,849+2,840 \mathrm{X} 4 \\
& -2.372 \mathrm{X} 5
\end{aligned}
$$

$\left(\mathrm{R}^{2}=0.761\right)$

$\mathrm{Y}=$ Function humanware component in the core industries.

Variable X1 (innovation) and X4 (trust fellow members) have a significant influence on humanware. Variable X2 (motivation), X3 (knowledge manager) and X5 (manager skill) has no effect on the level of $\alpha=0.05$.

Components that influence the results of the analysis using the SPSS is "innovation" and "trust fellow members". Effort required to develop technological innovation in order to increase the competitiveness of the product. Innovation is needed in leadership at the company. Motivation in doing business there are 3 types [15].

1) Traditional Model. This model is based on the assumption that the worker does not like his job. In this case the leader needs to provide clear directions and instructions, and oversees the implementation of jobs. Giving a high incentive needed to improve motivation in the work.

2) Model of Human Relationships. In this model the workers became saturated with work routines. This resulted in a decrease in the motivation to work. In this case the social relationships is needed. Workers in dire need of its existence in the works. For that leaders must be able to create a harmonious working environment and provide an appreciation of the good work.

3) Model of Human Resources. This model states that there are two types of workers, who first lazy workers carry out their duties. For that leaders must force him to work by providing incentives. The second type is a worker who enjoys his job. Workers of this type have a high innovation and creativity. Leaders only create conditions conducive to work.

Trust among members is one of the important social capital in the development of industrial clusters. Social capital will affect a wide range of activities in the improvement of public welfare. The interaction of all components of society is strongly influenced by social 
capital. One important component of social capital is social trust. It determines the quality of social capital possessed. Low social capital results in each individual mutual distrust. Therefore in order to develop industrial clusters well then required serious attention to social capital [17].

\section{CONCLUSIONS}

The survey results revealed that the industrial component is influenced by the core industry (level of difficulty in capital gain and raw materials), the buyer (customer satisfaction), related industry (quality and continuity of supply of packaging) and institutional support (coaching on marketing and capitalization as well as guidance on the production of sanitary and food safety). Component technology is influenced by organoware (production management and marketing management) and humanware (innovation and trust among the members).

\section{ACKNOWLEDGMENT}

Thanks go to the department of agriculture and industry and trade department of West Sumatra province which has facilitated the implementation of this study.

\section{REFERENCES}

[1] Anatan, L., and Ellitan, L. 2008. Supply Chain Management. Theory and Applications. Publisher Alfabeta.

[2] Bungin, B. 2010. Qualitative Research Data Analysis. PT King Grafindo Perkasa, Jakarta.

[3] Clark, J.R., Dwight R. Lee. 2006. Freedom, Entrepreneurship and Economic Progress. Journal of Entrepreneurship, USA, Vol. 15, No. 1, 1-17 (2006)

[4] Consumption and Food Safety Center. 2009. Acceleration of Food Consumption and Nutrition. Papers in Economics and Nutrition Improvement Seminar Family

[5] Daryanto, and Abdullah. 2013. Introduction to Management Science and Communication. Publisher Performance Library. Jakarta
[6] Devanath T. 2008. Role of Technological Innovations for Competitiveness and Entrepreneurship. Journal of Entrepreneurship India, Vol. 17, No. 2, 103-115 (2008).

[7] Department of Industry and Trade Cooperative West Sumatra. 2011. Cooperative Industry and Commerce of West Sumatra in Figures 2010 .

[8] Department of Food Crops of West Sumatra province. 2014. Profile Groups UP3HP in West Sumatra. Department of Food Crops of West Sumatra, Padang.

[9] Hendrastuti. 2012. Design of Rural Community Empowerment Model in Agro-Industry Cluster Essential Oils. Dissertation at the Graduate School of Bogor Agricultural University

[10] Hilmed. 2003. Development Strategy Agibisnis Commodity Subsector Sawahlunto Plantation in West Sumatra province. Bogor Agricultural University, Bogor.

[11] Marijan, K. 2005. Developing Small and Medium Industries through the Cluster Approach. Faculty of Social and Political Sciences, University of Airlangga, Surabaya.

[12] Ministry of Industry. 2009. Road Map of Industrial Cluster Development of Small and Medium 2014 - 2014. Ministry of Industry of the Republic of Indonesia. Jakarta.

[13] Muharram, the US, and Sofian, S. 2011. Analysis of Product Packaging Design and power Pull Ad on Brand Awareness and Impact on Consumer buying interest. Diponegoro University

[14] Nu'man, A.H. 2008. Small and Medium Industries Development Policy As A Strategy to Increase Competitiveness in the Era of Free Trade. Central Library ITB, Bandung.

[15] Porter, M.E. 2011. Creating shared value: Redefining Capitalsm and the Role of the Corporation in Society. Harvard Business School, USA.

[16] Purwanto, I. 2012. Management Strategy. Publisher CV Yrama Widya Bandung

[17] Respati, N.P. 2012. Effect of Interest in Packaging Design Chocolate Monggo To Buy Consumer Interests (eksplanatif Quantitative Study of the Visitors Center By - By Mirota Batik Yogyakarta Malioboro). Thesis at the University of Atma Jaya Yogyakarta

[18] Taufik, T. 2008. Beyond Thought Industry Cluster. Papers on "Cluster Development Discussion industry was in Indonesia, dated December 14, 2008, in Jakarta.

[19] Wibowo, Y. 2011. Design of Industrial Cluster Development Model Sustainable Seaweed. Dissertation In the Graduate School of Bogor Agricultural University. 